\title{
Assessment of the Phytonutrient Content, Mineral and Proximate Compositions of Selected Yam Landraces (Dioscorea Rotundata Poir)
}

\author{
Nwankwo PO* \\ National Root Crops Research Institute, Nigeria \\ *Corresponding author: Nwankwo PO, National Root Crops Research Institute, \\ Umudike, Umuahia, Abia State, Nigeria, Email: pastornwankwo@yahoo.com
}

\section{Research Article \\ Volume 4 Issue 3}

Received Date: April 05, 2019

Published Date: May 03, 2019

DOI: $10.23880 / \mathrm{ijbp}-16000157$

\begin{abstract}
The phytochemical screening, assessment of mineral and proximate compositions of eleven selected yam landraces were carried out using standard laboratory protocols with the view to gain insight to its nutritional and health potentials. Phytonutrient composition (mg/100g) analyses were carried out using different extraction solvents namely diethyl ether, ethanol, methanol, acetone and methanol. The results revealed that the eleven samples studied had alkaloid between the range of $(0.22-0.40)$, flavonoid (2.96 - 3.51), saponin (2.89 - 1.89), tannin (0.03 - 0.05), phytate $(0.001-0.02)$ and oxalate $(0.04-0.06)$. All observed phytonutrients were below toxic level and thus essential for good health and vitality. Mineral elements $(\mathrm{mg} / 100 \mathrm{~g})$ - calcium, magnesium, sodium, phosphorus, potassium, iron, zinc and copper were assessed. The eleven selected yam landraces had relatively high contents (within the WHO recommendations) of the assessed mineral elements such as calcium (16.47 - 91.32), magnesium (38.16 - 76.90), phosphorus (157.97 - 269.33), etc. The results of the proximate compositions showed that crude fibre was highest in Ogoja (2.36). Okpani had the highest content of crude protein (5.33) while Adaka had the highest content of crude fat (0.82). The caloric values $(\mathrm{Cal} / 100 \mathrm{~g})$ ranged from $150.32-193.57$ respectively.
\end{abstract}

Keywords: Dioscorea Rotundata; Phytonutrient; Mineral and Proximate Compositions

\section{Introduction}

Yams are important in the economic and social lives of Nigerians in particular and other tropical African countries in general; where they serve as one of the staple foods [1]. Yams contain mainly carbohydrate, thus are a cheap source of caloric energy. They also provide some minerals and essential vitamins, although a proportion of the minerals and vitamins may be lost during processing [2].
White yam (Dioscorea rotundata Poir) which originated in Africa is the most widely grown and preferred yam species. The tuber is roughly cylindrical in shape, the skin is smooth and brown and the flesh usually white and firm. A large number of white yam cultivars exist with differences in their production, nutritional qualities and post - harvest characteristics. 


\section{International Journal of Biochemistry \& Physiology}

Landraces are those cultivars that have been in existence and have been in use over a long period of time. They could be regarded as accessions (i.e. yams that are not yet characterized). They are not hybrids. They are mostly disease resistant, high yielding and possess other preferred traits by the farmers. They make significant contributions in the diet of the people, or as varieties in the farming system of the people or even as progenitors in breeding program for the farmer preferred traits. The nutritional quality of the yam landraces have not been fully elucidated as to ascertain their food values. However, the analyses of the phytonutrient, mineral and proximate compositions of these landraces constitute an important index of their food quality and can elucidate useful information on the nutritional quality and authenticity of food products and sources of raw materials used in food manufacture. For one to stimulate the consumption and mass production of the various landraces there is therefore need for the research on their nutritional assessment. The aim of this research is to identify the need for the preservation of these yam landraces (based on their nutritional values) rather than completely replacing them with the new varieties. The results of this investigation will be useful information to the nutritionists, chemists, farmers and consumers who are constantly in search of additional food sources and products for the general wellbeing of mankind as well as animals.

\section{Material and Methods}

The current study was conducted in Biochemistry Laboratory of National Root Crops Research Institute, Umudike.

Yam source: The selected yam landraces were obtained from the yam barn of National Root Crops Research Institute, Umudike.

Chemicals: All chemicals used in the investigation were of analytical grade.

Production of yam flour: Yam four was produced according to the method of Ukpabi and Oti [3].

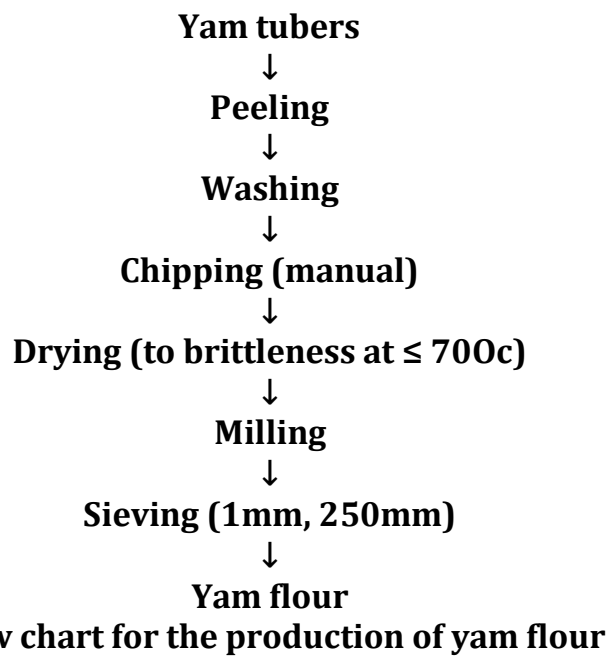

Quantitative determination of phytochemical constituents: Phytochemical screening of the samples was carried out using standard phytochemical quantitative analyses.

\section{Determination of Alkaloid}

Quantitative determination of alkaloid was carried out according to the method of Harborne (1998) [4]. Exactly $200 \mathrm{~cm}^{3}$ of $10 \%$ acetic acid in ethanol was added to each sample $(2.50 \mathrm{~g})$ in a $250 \mathrm{~cm}^{3}$ beaker and allowed to stand for 4 hours. The extract was concentrated on a water bath to one-quarter of the original volume followed by addition of 15 drops of concentrated ammonium hydroxide drop wise to the extract until the precipitation was complete. After 3hours of mixture sedimentation, the supernatant was discarded and the precipitates were washed with $20 \mathrm{~cm}^{3}$ of $0.1 \mathrm{M}$ ammonium hydroxide and then filtered using Whatman filter paper. The residue was dried in an oven and using an electronic weighing balance, the alkaloid content was calculated.

\section{Determination of Flavonoid}

Flavonoid determination was carried out by the method of Ejikeme, et al. [5] and Boham and Kocipai [6]. Exactly $50 \mathrm{~cm} 3$ of $80 \%$ aqueous methanol was added to $2.50 \mathrm{~g}$ of each of the samples in a beaker covered and 


\section{International Journal of Biochemistry \& Physiology}

allowed to stand for 24 hours at room temperature. After discarding the supernatant, the residue was re-extracted (thrice) with the same volume of ethanol. Whatman filter paper $(125 \mathrm{~mm})$ was used to filter whole solution of each sample. Each sample filtrate was later transferred into a crucible and evaporated to dryness over a water bath. The content in the crucible was cooled in a desiccator and weighed until constant weight was obtained.

\section{Determination of Saponin}

Quantitative determination of saponin was done by the method reported by Obadoni and Ochuko [7] and Ejikeme, et al. [5]. Exactly $100 \mathrm{~cm}^{3}$ of $20 \%$ aqueous ethanol was added to $5 \mathrm{~g}$ of sample in a $250 \mathrm{~cm}^{3}$ conical flask. The mixture was heated over a hot water bath for 4hours with continuous stirring at a temperature of $55^{\circ} \mathrm{C}$. The residue of the mixture was re-extracted with another $100 \mathrm{~cm}^{3}$ of $20^{\circ} \mathrm{C}$ aqueous ethanol after filtration and heated for 4 hours at a constant temperature of $55^{\circ} \mathrm{C}$ with constant stirring. The combined extract was evaporated to $40 \mathrm{~cm}^{3}$ over water bath at $90^{\circ} \mathrm{C} .20 \mathrm{~cm}^{3}$ of diethyl ether was added to the concentrate in a $250 \mathrm{~cm}^{3}$ separator funnel and vigorously agitated from which the aqueous layer was recovered while the ether layer was discarded. This purification process was repeated twice. $60 \mathrm{~cm}^{3}$ of nbutanol was added and extracted twice with $10 \mathrm{~cm}^{3}$ of $5 \%$ sodium chloride. After discarding the sodium chloride layer, the remaining solution was heated in a water bath for 30 minutes, after which the solution was transferred into a crucible and was dried in an oven to a constant weight.

\section{Determination of Tannin}

Four hundred milligram (400mg) of each of the samples was placed into two conical flasks. $40 \mathrm{ml}$ of diethyl ether containing $1 \%$ acetic acid was added and centrifuged to remove the pigments. The precipitate was dissolved in $20 \mathrm{ml}$ of $70 \%$ acetone. The flasks were sealed with cotton plug covered with aluminum foil, then kept in a shaker for 2 hours. Each of the contents in the flask was filtered through Whatman filter paper. $0.5 \mathrm{ml}$ of filtrate was made up to $1 \mathrm{ml}$ with distilled water. $0.5 \mathrm{ml}$ of folin ciocalteau reagent was added and mixed with $2.5 \mathrm{ml}$ of $20 \%$ sodium carbonate solution and mixed. The mixtures were kept for 40 minutes at room temperature. The absorbance was measured by spectrophotometer using tannin as standard.

\section{Determination of Oxalate}

Oxalate content was determined using the method described by Harborne [4]. One gram (1g) of the sample was dissolved in $190 \mathrm{ml}$ of distilled water. $10 \mathrm{ml}$ of $6 \mathrm{M} \mathrm{HCl}$ was added to it and the mixture was warmed in water bath at $90^{\circ} \mathrm{C}$ for 4 hours. The mixture was then centrifuged at a speed of 2000rpm for 5 mins. The supernatant was diluted and evaporated. The precipitate was filtered off and titrated with ammonium solution until the methyl orange colour changed to faint yellow. The solutions were heated at $90^{\circ} \mathrm{C}$ and the oxalate was precipitated with $10 \mathrm{ml}$ of $5 \%$ calcium chloride solution. Each precipitate was washed with $25 \% \mathrm{H}_{2} \mathrm{SO}_{4}$, diluted to $125 \mathrm{ml}$ and warmed at $90^{\circ} \mathrm{C}$. It was titrated against $0.05 \mathrm{M}$ potassium permanganate.

\section{Determination of Phytate}

The phytate content was determined according to the method of Ejikeme, et al. (2014) [5]. Two grams (2g) of each of the samples was weighed and soaked in $100 \mathrm{ml}$ of $2 \% \mathrm{HCl}$ for 3 hours, the filtered through a double layer thick filter paper. $50 \mathrm{ml}$ of each filtrate was made up to $150 \mathrm{ml}$ with distilled water. $10 \mathrm{ml}$ of ammonium thiocyanate solution was added as indicator. Each solution was titrated against standard iron chloride solution which contain $0.00195 \mathrm{~g}$ of iron per ml till a constant coloration was obtained. The phytate content was calculated.

\section{Determination of the Mineral Composition}

The mineral composition was determined according to the method described by Larrauri, et al. [8]. The ash was dissolved in $\mathrm{HNO}_{3}$ with $50 \mathrm{~g} / \mathrm{l}$ of $\mathrm{LaCl}_{3}$ and the mineral contents Calcium (Ca), Magnesium (Mg), sodium ( $\mathrm{Na}$ ), iron (Fe), and potassium (K) were analyzed separately using an atomic absorption spectrophotometer. One gram (1g) of sample was digested with $20 \mathrm{ml}$ of $2: 1 \mathrm{HNO}_{3} / \mathrm{HClO}_{4}$ and heated until white fumes were evolved. The digested samples were then filtered into standard $50 \mathrm{ml}$ volumetric flask and made up to the mark with distilled water. The minerals, copper $(\mathrm{Cu})$ and zinc $(\mathrm{Zn})$ were determined using air acetylene flame atomic absorption spectrometry. Glassware used for analyses were thoroughly cleaned and all reagents used were of analytical grade. Phosphorus content of the samples was determined colorimetrically according to the method described by Obadoni and Ochuko, [7].

\section{Determination of the Proximate Composition}

The ash, crude fat, crude fibre and moisture contents of the eleven selected yam landraces were determined using the standard method of AOAC, 1990. Crude protein was determined by the Kjeldahl method as described by Okalebo, et al. [9], and expressed as (\%N X 6.25), where 


\section{International Journal of Biochemistry \& Physiology}

$\% \mathrm{~N}$ represents percentage nitrogen. Carbohydrate content was obtained by difference. Carbohydrate $=100-$ (moisture + ash + crude protein + crude fat + crude fibre) .

The caloric values of the selected landraces were obtained using the Atwater factor method: (4 X Carbohydrate $)+(4$ X Crude protein $)+(9$ X Crude fat $)$.

\section{Statistical Analysis}

The experiments were carried out in five determinations and data collected were expressed as the mean \pm standard deviation.

\section{Results and Discussions}

The eleven yam land races collected from the yam barn of National Root Crops Research Institute, Umudike were selected for the present studies to characterize for phytonutrient, mineral and proximate compositions.

The results of the phytonutrient contents of the eleven selected yam landraces are presented in Table 1. The eleven selected yam landraces have alkaloid ranging from $(0.22-0.40)$. Alkaloids are a diverse group of secondary metabolites and show antimicrobial activity by inhibiting DNA topoisomerase [10]. Alkaloids affect a lot of metabolic activities in the body, but when in high concentration is toxic to man [7]. The flavonoid content of the samples was relatively high with Okpani (3.94) having the highest content of flavonoid followed by Miyango (3.51). In vitro studies have shown that flavonoids have a wide range of biological and pharmacological activities such as anti-inflammatory [11], antioxidant [12], antimicrobial [13], antidiabetic [14], etc. This shows that Okpani as well as the other landraces could serve as useful sources of antioxidants due to increased content of flavonoids. The highest content of saponin (2.89) was found in Okpani followed by Adaka (2.80). Saponins are components of glycosides and are often referred to as natural detergents, because of their foamy nature. They are known to have both beneficial and deleterious properties depending on their concentrations. They have been reported to possess anticarcinogenic properties [15], immune modulation activities, regulation of cell proliferation as well as health benefits such as inhibition of the growth of cancer cells and cholesterol lowering activity [16]. Both Ogoja and Gwagwa had the highest value of tannins (0.05) respectively, followed by Aloshe, Amola, Dorban, Hemba and Okpani which had $(0.04$ $\mathrm{mg} / 100 \mathrm{~g}$ of tannin).Tannin is one of the important secondary metabolites which reduce the risk of coronary heart diseases [17]. The eleven selected yam landraces had oxalate ranging between $(0.04-0.06)$. Studies have shown that oxalate may play various roles in plants including calcium regulation, ion balance, plant protection, tissue support and heavy metal detoxification Nakata [18]. However when in excess, oxalate poisoning occurs. Ingested oxalate complexes with other mineral elements such as calcium to form calcium oxalate. This can lead to disturbances in calcium and phosphorus metabolism, involving excessive mobilization of bone minerals thus causing dimineralized bones $[19,20]$. The phytate content of the selected samples were also below toxic levels and range from $(0.01-0.02)$. Phytates are phytic acid bound to a mineral. Phytic acids are the storage forms of phosphorus [21]. Phytic acid has a strong ability to chelate multivalent metal ions, especially zinc, calcium and iron. The binding can result in very insoluble salts with poor bioavailability of minerals [22]. These low contents of phytochemical contained in these yam landraces show that they are not harmful to health but rather are useful sources health-maintenance components. However, only inositol pentaphosphate (IP5) and inositol hexaphosphate (IP6) have a negative effect on bioavailability of minerals. Besides its wellknown negative properties IP6 by complexing iron may bring about a favourable reduction in the formation of hydroxyl radicals in the colon and also positive effect against carcinogenesis have been shown with in vitro cell culture systems [23]. All studied samples are rich in phytochemical and thus could be recommended for nutritional balances and health management.

\begin{tabular}{|c|c|c|c|c|c|c|}
\hline Yam Landraces & Alkaloid & Flavonoid & Saponin & Tannin & Oxalate & Phytate \\
\hline Adaka & $0.29 \pm 0.01$ & $3.05 \pm 0.01$ & $2.8 \pm 0.01$ & $0.03 \pm 0.01$ & $0.06 \pm 0.01$ & $0.01 \pm 0.01$ \\
\hline Aloshe & $0.34 \pm 0.01$ & $3.01 \pm 0.01$ & $1.99 \pm 0.02$ & $0.04 \pm 0.01$ & $0.05 \pm 0.01$ & $0.02 \pm 0.01$ \\
\hline Ameh & $0.36 \pm 0.01$ & $3.07 \pm 0.02$ & $2.79 \pm 0.02$ & $0.05 \pm 0.01$ & $0.06 \pm 0.01$ & $0.00 \pm 0.00$ \\
\hline Amola & $0.26 \pm 0.02$ & $2.99 \pm 0.02$ & $2.01 \pm 0.01$ & $0.04 \pm 0.01$ & $0.04 \pm 0.01$ & $0.02 \pm 0.01$ \\
\hline Dorban & $0.28 \pm 0.01$ & $3.66 \pm 0.06$ & $2.62 \pm 0.02$ & $0.04 \pm 0.01$ & $0.04 \pm 0.01$ & $0.00 \pm 0.00$ \\
\hline Gwagwa & $0.40 \pm 0.02$ & $3.07 \pm 0.01$ & $2.41 \pm 0.38$ & $0.05 \pm 0.01$ & $0.05 \pm 0.01$ & $0.02 \pm 0.01$ \\
\hline Heabalo & $0.24 \pm 0.01$ & $3.11 \pm 0.01$ & $2.19 \pm 0.02$ & $0.03 \pm 0.01$ & $0.04 \pm 0.01$ & $0.01 \pm 0.01$ \\
\hline Hemba & $0.22 \pm 0.02$ & $3.01 \pm 0.01$ & $1.99 \pm 0.03$ & $0.04 \pm 0.01$ & $0.04 \pm 0.01$ & $0.01 \pm 0.01$ \\
\hline
\end{tabular}




\section{International Journal of Biochemistry \& Physiology}

\begin{tabular}{|c|c|c|c|c|c|c|}
\hline Miyango & $0.36 \pm 0.01$ & $3.51 \pm 0.02$ & $2 \pm 0.02$ & $0.03 \pm 0.01$ & $0.05 \pm 0.01$ & $0.00 \pm 0.00$ \\
\hline Ogoja & $0.32 \pm 0.01$ & $2.96 \pm 0.06$ & $1.89 \pm 0.02$ & $0.05 \pm 0.01$ & $0.04 \pm 0.01$ & $0.01 \pm 0.01$ \\
\hline Okpani & $0.35 \pm 0.05$ & $3.94 \pm 0.02$ & $2.89 \pm 0.02$ & $0.04 \pm 0.01$ & $0.05 \pm 0.01$ & $0.00 \pm 0.00$ \\
\hline
\end{tabular}

Table 1: Phytonutrient composition (mg/100g) of the selected yam landraces.

* Mean of five determinations \pm standard deviation.

Mineral content is the measure of the amount of specific inorganic components present within a food. Calcium (Ca), magnesium (Mg), phosphorus (P), potassium $(\mathrm{K})$, sodium $(\mathrm{Na})$, iron $(\mathrm{Fe})$, zinc $(\mathrm{Zn})$ and copper $(\mathrm{Cu})$ contents are shown in Table 2. All samples studied showed that the mineral contents of the landraces were appreciably high making them a good source of nutritional components. The highest content of calcium was found in Hemba (91.32), followed by Gwagwa (89.61) and then Okpani (80.11). Phosphorus content of all the samples under investigation were high, with Okpani (269.33) having the highest value. Inorganic phosphorus (compound containing the phosphate ion, $\mathrm{PO}_{4}{ }^{-3}$ ) is a component of DNA, RNA, ATP and also the phospholipids which help in the formation of all cell membranes. Calcium phosphate salts assist in formation of healthy bones and teeth. An appreciable percentage of phosphorus is present in bones and teeth in the form of apatite and the remainder in soft tissues and extracellular fluids [21]. Hypophosphatamia could cause muscle and neurological dysfunction, disruption of muscle and blood cells due to lack of ATP. Consumption of any of these landraces which contained high values of these mineral elements could be recommended in the absence of/or in place of milk, meat and soya which are rich in phosphorus. The result showed that Ogoja had the highest potassium content (900.09). Potassium plays a role in many body functions including transmission of nerve signals, muscle contractions, fluid balance and various chemical reactions [24]. However, increased rate of death of any cause, some cardiac, kidney and lung disease progress more rapidly if serum potassium levels are not maintained at normal range $[25,26]$. Minerals especially calcium, phosphorus and potassium are required in human body in large amounts. Their deficiency results in arthritis, bone and teeth related disorders. Aloshe was highest in sodium content (81.61), followed by Hemba (73.80) while Okpani had (61. 51) sodium content. In humans, sodium is an essential nutrient that regulates blood volume, blood pressure, osmotic equilibrium and $\mathrm{pH}$ [27]. Sodium chloride $(\mathrm{NaCl})$ is the principal source of sodium in the diet and is used as seasoning and preservative. The ratio of sodium/potassium $(\mathrm{Na} / \mathrm{K})$ less than 1 is recommended for the body. All samples studied showed $\mathrm{Na} / \mathrm{K}$ ratio less than one $(\mathrm{Na} / \mathrm{K}<1)$, thus would not promote high blood pressure. Excess sodium in the diet could lead to hypertension. Aloshe had the highest magnesium content (76.90) followed by Heabalo (73.01). Magnesium is important for energy metabolism and protein synthesis. It is required for the proper growth and maintenance of bones, proper functioning of nerves, muscles and many other parts of the body [28]. In the stomach, magnesium helps to neutralize stomach acid and moves stool through the intestine. The UK recommended daily intake of magnesium for adults is between 250 $350 \mathrm{mg} /$ day [29]. Iron and zinc had relatively appreciable values in the eleven selected yam landraces. Iron forms complexes with molecular oxygen in hemoglobin and myoglobin which are common oxygen transport proteins in vertebrates [30]. Iron is also the metal at the active site of many important redox enzymes dealing with cellular respiration, oxidation/reduction in plants and animals [31]. The dietary reference intake (DRI) lists tolerable upper intake level for adults as $45 \mathrm{mg} /$ day and $40 \mathrm{mg} /$ day for children less than 14 years [32,33]. Zinc plays an important role in more than 300 enzymes involved in synthesis and degradation of biomolecules, metabolism of other micronutrients as well as the immune system [34]. However the bioavailability of zinc may be adversely affected by anti-nutritional factors [35]. In all the samples studied, copper content was relatively very low with Adaka having the highest content (0.17). Copper is essential to all living organisms as a trace dietary mineral because it is a key constituent of the respiratory enzyme complex cytochrome c- oxidase. In humans, copper is mainly found in the liver, muscle and bone [36]. Copper plays an important role in a wide range of physiological processes in the body which include iron utilization, elimination of free radicals, development of bone and connective tissues and production of skin and hair pigment called melanin. The RDA for copper in normal healthy adults is quoted as $0.97 \mathrm{mg} /$ day [37]. The eleven selected yam landraces could be recommended for zinc and copper mineral elements as their values are below the WHO limit for zinc $(100 \mathrm{mg} / \mathrm{kg})$ and copper $(50 \mathrm{mg} / \mathrm{kg})$ respectively. Thus consumption of any of the yam landraces will make for adequate copper supply in the diet. 


\section{International Journal of Biochemistry \& Physiology}

\begin{tabular}{|c|c|c|c|c|c|c|c|c|}
\hline $\begin{array}{c}\text { Yam } \\
\text { Landraces }\end{array}$ & $\begin{array}{c}\text { Calcium } \\
(\mathbf{C a})\end{array}$ & $\begin{array}{c}\text { Magnesium } \\
(\mathbf{M g})\end{array}$ & $\begin{array}{c}\text { Sodium } \\
(\mathbf{N a})\end{array}$ & $\begin{array}{c}\text { Phosphorus } \\
(\mathbf{P})\end{array}$ & $\begin{array}{c}\text { Potassium } \\
(\mathbf{K})\end{array}$ & $\begin{array}{c}\text { Iron } \\
(\mathbf{F e})\end{array}$ & $\begin{array}{c}\text { Zinc } \\
(\mathbf{Z n})\end{array}$ & $\begin{array}{c}\text { Copper } \\
(\mathbf{C u})\end{array}$ \\
\hline Adaka & $29.5 \pm 0.02$ & $61.5 \pm 0.02$ & $61.14 \pm 0.03$ & $164.51 \pm 0.02$ & $614.45 \pm 0.12$ & $0.23 \pm 0.02$ & $2.61 \pm 0.01$ & $0.17 \pm 0.02$ \\
\hline Aloshe & $62.52 \pm 0.02$ & $76.9 \pm 0.02$ & $81.61 \pm 0.03$ & $189.91 \pm 0.03$ & $670.03 \pm 0.03$ & $0.48 \pm 0.04$ & $1.93 \pm 0.07$ & $0.11 \pm 0.02$ \\
\hline Ameh & $16.47 \pm 0.04$ & $41.52 \pm 0.02$ & $60.53 \pm 0.02$ & $157.97 \pm 0.46$ & $474.8 \pm 0.38$ & $0.32 \pm 0.02$ & $1.69 \pm 0.02$ & $0.11 \pm 0.01$ \\
\hline Amola & $20.48 \pm 0.03$ & $67.51 \pm 0.02$ & $69.42 \pm 0.08$ & $211.62 \pm 0.02$ & $611.3 \pm 0.02$ & $0.43 \pm 0.02$ & $1.35 \pm 0.02$ & $0.09 \pm 0.02$ \\
\hline Dorban & $74.3 \pm 0.02$ & $55.49 \pm 6.33$ & $70.28 \pm 0.09$ & $239.13 \pm 0.06$ & $623.53 \pm 0.1$ & $0.34 \pm 0.02$ & $2.12 \pm 0.02$ & $0.12 \pm 0.02$ \\
\hline Gwagwa & $89.61 \pm 0.04$ & $40.04 \pm 0.03$ & $62.54 \pm 0.01$ & $219.19 \pm 0.07$ & $711.3 \pm 0.02$ & $0.3 \pm 0.01$ & $2.42 \pm 0.02$ & $0.11 \pm 0.02$ \\
\hline Heabalo & $27.3 \pm 0.12$ & $73.01 \pm 0.01$ & $72.1 \pm 0.03$ & $190.5 \pm 0.03$ & $704.54 \pm 0.12$ & $0.21 \pm 0.02$ & $1.72 \pm 0.04$ & $0.1 \pm 0.05$ \\
\hline Hemba & $91.32 \pm 0.05$ & $54.11 \pm 0.04$ & $73.8 \pm 0.06$ & $224.78 \pm 0.03$ & $804.32 \pm 0.1$ & $0.48 \pm 0.04$ & $1.48 \pm 0.03$ & $0.1 \pm 0.02$ \\
\hline Miyango & $40.1 \pm 0.03$ & $38.16 \pm 0.07$ & $66.74 \pm 0.08$ & $193.13 \pm 0.02$ & $760.01 \pm 0.03$ & $0.27 \pm 0.03$ & $1.72 \pm 0.02$ & $0.09 \pm 0.03$ \\
\hline Ogoja & $78.73 \pm 0.02$ & $43.5 \pm 0.02$ & $53.33 \pm 0.03$ & $200.15 \pm 0.02$ & $900.09 \pm 0.17$ & $0.21 \pm 0.01$ & $1.88 \pm 0.01$ & $0.1 \pm 0.02$ \\
\hline Okpani & $80.11 \pm 0.02$ & $43.62 \pm 0.02$ & $61.51 \pm 0.03$ & $269.33 \pm 0.03$ & $795.82 \pm 0.02$ & $0.34 \pm 0.04$ & $1.81 \pm 0.02$ & $0.11 \pm 0.02$ \\
\hline
\end{tabular}

Table 2: Mineral composition (mg/100g) of the selected yam landraces (Dioscorea rotundata Poir).

* Mean of five determinations \pm standard deviation.

The results of the proximate composition of the selected yam land races are presented in Table 3. The highest moisture content (61.05) was found in Heabalo, followed by Okpani (60.02). The high moisture contents observed in the fresh tubers is an indication that the tubers may be prone to microbial attack. Hemba contained the highest ash content (1.09), followed by Okpani (0.69). Ash content is a measure of the total amount of minerals present within a food. Ash is the inorganic residue remaining after the water and organic matter have been removed by heating. The highest crude fibre content was found in Ogoja (2.36). The high fibre content ranging from $(1.4-2.36)$ in the selected yam landraces is an indication that they are good sources of fibre and thus may play useful role in digestion and reduction in the incidence of various disorders such as colon cancer, constipation, diabetes, etc. [38]. Okpani contained the highest crude protein content (5.33) followed by Miyango (5.12). Protein is essential for the repair of damaged tissues and for the building up of new ones. It is the main building block in the body. Crude fat content was highest in Adaka (0.82) followed by Ameh (0.81). Fats are the slowest sources of energy but the most energy-efficient form of food. Each gram of fat supplies the body with about 9 calories, more than twice that supplied by proteins and carbohydrates. All samples were shown to have moderately high contents of carbohydrate and consequently caloric values. Carbohydrates are the main sources of energy and they tend to provide energy to the body more quickly than protein and fat. Carbohydrates, proteins and fats are needed by the body for growth, maintenance and other cellular activities. On account of the proximate composition, Okpani was found to be best (Table 3).

\begin{tabular}{|c|c|c|c|c|c|c|c|}
\hline $\begin{array}{c}\text { Yam } \\
\text { Species }\end{array}$ & Moisture & Ash & Crude fibre & Crude protein & Crude fat & Carbohydrate & $\begin{array}{c}\text { Caloric value } \\
(\text { Cal/100g) }\end{array}$ \\
\hline Adaka & $56.45 \pm 0.12$ & $0.49 \pm 0.34$ & $1.57 \pm 0.03$ & $4.01 \pm 0.02$ & $0.82 \pm 0.02$ & $36.56 \pm 0.14$ & $169.61 \pm 0.57$ \\
\hline Aloshe & $55.77 \pm 0.06$ & $0.68 \pm 0.02$ & $1.25 \pm 0.01$ & $3.04 \pm 0.03$ & $0.42 \pm 0.01$ & $38.85 \pm 0.09$ & $171.31 \pm 0.35$ \\
\hline Ameh & $54.53 \pm 0.28$ & $0.64 \pm 0.01$ & $1.74 \pm 0.01$ & $3.81 \pm 0.03$ & $0.81 \pm 0.02$ & $38.46 \pm 0.29$ & $176.36 \pm 1.17$ \\
\hline Amola & $59.12 \pm 0.03$ & $0.64 \pm 0.01$ & $1.65 \pm 0.03$ & $4.25 \pm 0.02$ & $0.45 \pm 0.01$ & $33.9 \pm 0.08$ & $156.61 \pm 0.22$ \\
\hline Dorban & $50.97 \pm 0.38$ & $0.64 \pm 0.01$ & $1.43 \pm 0.03$ & $3.16 \pm 0.03$ & $0.51 \pm 0.01$ & $43.29 \pm 0.35$ & $190.4 \pm 1.48$ \\
\hline Gwagwa & $52.91 \pm 0.22$ & $0.64 \pm 0.01$ & $1.4 \pm 0.01$ & $3.7 \pm 0.02$ & $0.5 \pm 0.02$ & $40.85 \pm 0.22$ & $182.67 \pm 0.8$ \\
\hline Heabalo & $61.05 \pm 0.47$ & $0.48 \pm 0.03$ & $1.71 \pm 0.01$ & $2.88 \pm 0.01$ & $0.65 \pm 0.04$ & $33.24 \pm 0.52$ & $150.32 \pm 1.9$ \\
\hline Hemba & $56.61 \pm 0.04$ & $1.09 \pm 0.01$ & $2.26 \pm 0.02$ & $4.18 \pm 0.03$ & $0.74 \pm 0.01$ & $35.12 \pm 0.05$ & $163.88 \pm 0.31$ \\
\hline Miyango & $50.43 \pm 0.08$ & $0.35 \pm 0.02$ & $1.4 \pm 0.02$ & $5.12 \pm 0.02$ & $0.47 \pm 0.01$ & $42.23 \pm 0.09$ & $193.57 \pm 0.22$ \\
\hline Ogoja & $58.32 \pm 0.05$ & $0.44 \pm 0.01$ & $2.36 \pm 0.01$ & $3.69 \pm 0.01$ & $0.53 \pm 0.03$ & $34.67 \pm 0.08$ & $158.18 \pm 0.24$ \\
\hline Okpani & $60.02 \pm 0.31$ & $0.69 \pm 0.01$ & $2.02 \pm 0.02$ & $5.33 \pm 0.02$ & $0.46 \pm 0.16$ & $31.48 \pm 0.38$ & $151.56 \pm 1.66$ \\
\hline
\end{tabular}

Table 3: Proximate composition (\%) of the selected yam landraces.

* Mean of five determinations \pm standard deviation 


\section{International Journal of Biochemistry \& Physiology}

\section{Conclusion and Recommendation}

Phytonutrient, mineral and proximate compositions assessment of the eleven selected yam landraces showed that the landraces are endowed with phytochemical and nutritional constituents that could play a role in health maintenance. The landraces contain appreciable quantities of phytochemical which possess lots of medicinal properties and thus may be useful in pharmaceutical industries. The findings may also be useful for quality control and nutrient-health promotion campaign. Furthermore, this study presents the landraces for future pharmacological and therapeutic studies in related research field.

\section{References}

1. Otegbayo BO, Asiedu R, Bokanga M (2011) Effect of storage on the chemical composition and food quality of yam. J Food Process Preserv 36(5): 438-445.

2. Nwankwo PO, Ukpabi UJ (2018) Biochemical composition and glucose syrup production potential of elite yam varieties from Benue State, Nigeria. Int J Biochem Physiol 3(5): 2577-4360.

3. Ukpabi UJ, Oti E (2010) Storage, processing and utilization of yam. In: Ukpabi UJ, Nwosu KI (Eds.), Yam, cocoyam and sweet potato production and post -harvest management. NRCRI Umudike, pp: 81-94.

4. Harborne JB (1998) Phytochemical methods. $3^{\text {rd }}$ (Edn.), Chapman and Hill, London, pp: 1-302.

5. Ejikeme CM, Ezeonu CS, Eboatu AN (2014) Determination of physical and phytochemical constituents of some tropical timbers indigenous to Niger Delta Area of Nigeria. European Scien J 10(18): 247-270.

6. Boham BA, Kocipai AR (1994) Flavonoids and condensed tannins from leaves of Hawaiian Vaccinium vaticulatum and $V$. calycinium. Pacific Sci 48(4): 458-463.

7. Obadoni BO, Ochuko PO (2001) Phytochemical studies and comparative efficacy of the crude extracts of some homeostatic plants in Edo and Delta States of Nigeria. Global J Pure Appl Sci 8(2): 203-208.

8. Larrauri JA, Ruperez P, Borroto B, Saura-Calixto F (1996) Mango peels as a new tropical fibre: preparation and characterization. LWT Food Sci Technol 29(8): 729-733.

9. Okalebo JR, Gathua KW, Woomer PL (2002) Laboratory methods of soil and plant analysis: A working manual. Open J Soil Sci 7(2): 47-93.

10. Ebuehi OAT, Babalola O, Ahmed S (2005) Phytochemical nutritive and anti-nutritive composition of cassava tubers and leaves. Nigerian Foods J 23(1): 40-46.

11. Yamamoto Y, Gaynor RB (2001) Therapeutic potential of inhibition of the NF - KB pathway in the treatment of inflammation and cancer. J Clin Investig 107(2): 135-142.

12. Bello IA, Ndukwe GI, Audu OT, Habila JD (2011) A bioactive flavonoid from Pavetta crassipes K. Schum. Organic Med Chem Lett 1(1): 14.

13. Cushnie TP, Lamb AJ (2011) Recent advances in understanding the antibacterial properties of flavonoids. Int J Antimicrob Agents 38(2): 99-107.

14. Babu PV, Liv D, Gilbert ER (2013) Recent advances in understanding the antidiabetic actions of dietary flavonoids. J Nutriti Biochem 24(11): 1777-1789.

15. Dini I, Tenore GC, Dini A (2009) Saponins in Ipomea batatas tuber: isolation, characterization, quantification and antioxidant properties. Food Chem 113(2): 411-419.

16. Sodipo OA, Akiniyi JA, Ogunbasu JU (2000) Studies on certain characteristics of extracts of bark of Pansinystallia macruceras (K. Schum). Pierve Exbeilla. Global J Pure Appl Sci 6(1): 83-87.

17. Ruyle R (2003) Oxalate and tannin assessment in Atriplex halimus L. and A. nummularia L. J Range Manag 56(4): 370-374.

18. Nakata PA (2003) Advances in our understanding of calcium oxalate crystal formation and function in plants. Plant Sci 164(6): 901-909.

19. Rahman MM, Ishii Y, Niimi M, Kawamura O (2010) Effect of application form of nitrogen on oxalate accumulation and mineral uptake by napiergrass (Pennisetum purpureum). Grassland Sci 56(3): 141144. 


\section{International Journal of Biochemistry \& Physiology}

20. Massey LK (2007) Food oxalate factors affecting measurement, biological variation and bioavailability. J Ame Diet Assoc 107(7): 1191-1194.

21. Adebooye OC, Oloyede FM (2007) Effect of phosphorus on the fruit yield and food value of two landraces of Trichosanthes cucumeria $\mathrm{L}$. Cucurbitaceae. Food Chem 100(3): 1259-1264.

22. Hotz C, Gibson RS (2007) Traditional food processing and preparation to enhance the bioavailability of micronutrients in plant-based diets. J Nutri 137(4): 1097-1100.

23. Vucenik I, Shamsuddin AM (2003) Cancer inhibition by inositol hexaphosphate (IP6) and inositol: from laboratory to clinic. J Nutr 133(11): 3778S-3784S.

24. D’Elia L, Barba G, Cappuccio F, Strazzullo G (2011) Potassium intake, stroke and cardiovascular disease: a meta-analysis of prospective studies. J Ame College Cardiol 57(10): 1210-1219.

25. Abhinav G, John AS, Kensey G, Lakshmi V, Philip GJ, et al. (2012) Serum potassium levels and mortality in acute myocardial infarction. JAMA 307(2): 157-164.

26. Smith A, Dunkler D, Gao P, Teo KK, Yusuf S, et al. (2014) The relationship between estimated sodium and potassium excretion and subsequent renal outcomes. Kidney Int 86(6): 1205-1212.

27. Geleijnse JM, Kok FJ, Grobbee DE (2004) Impact of dietary and lifestyle factors on the prevalence of hypertension in Western populations. Europ J Publ Heal 14(3): 235-239.

28. Ayuk J, Gittoes NJ (2014) Contemporary view of the clinical relevance of magnesium homeostasis. Ann Clin Biochem 51(2): 179-188.

29. Romani AMP (2013) Magnesium in health and diseases. Metal Ions Life Sci 13: 49-79.

30. Hoppe M, Hulthen L, Hallberg L (2005) The relative bioavailability in humans of elemental iron powders for use in food fortification. Europ J Nutr 45(1): 3744.
31. Wu H, Wu T, Xu X, Wang J, Wang J (2011) Iron toxicity in mice with collagenase-induce intracerebal hemorrhage. J Celebra Blood Flow Metabo 31(5): 1245-1250.

32. Institute of Medicine, Food and Nutrition Board Dietary References (2001) Intakes of vitamin A, K, Arsenic, Boron, Chromium, Copper, Iodine, Iron, Manganese, Molybdenum, Nickel, Silicon, Vanadium and Zinc: A report of the panel on micronutrients. D. C.: National Academy Press, Washington.

33. Baker RD, Greer FR (2010) Diagnosis and prevention of iron deficiency and iron-deficiency anemia in infants and young children (0 - 3 years of age). Pediatrics 126(5): 1040-1050.

34. MacDonald RS (2000) The role of zinc in growth and cell proliferation. J Nutri 130(5): 1500S-1508S.

35. World Health Organization (2009) Global prevalence of vitamin A deficiency in population at risk, 1995 2005. WHO Global Database on Vitamin A Deficiency. Geneva: World Health Organization.

36. Bonham M, O'Connor JM, Hannigan BM, Strain JJ (2002) The immune system as a physiological indicator of marginal copper status. Br J Nutri 87(5): 393-403.

37. Geoffrey MG (2010) Metals, minerals and microbes: geomicrobiology and bioremediation. Microbiol 156(3): 609-643.

38. Causey JL, Feirtag JM, Gallaher DD, Tungland BC, Slavian JL (2000) Effects of dietary inulin on serum lipids, blood glucose and gastro-intestinal environment in hypercholesterolemic men. Nut Res 20(2): 191-201.

39. Astrd S, Helmeut S, Roland KO (2013) Interrelations between essential metal ions and human diseases. Springer, Netherlands.

40. Trease GE, Evans WC (2002) Phrmacognosy. 15th (Edn.), Harcourt Publishers, Edinburgh UK, pp: 625705. 